\title{
SANDWICH ON A MISSION: POLYTROPIC VAGARIES IN LESTRYGONIANS
}

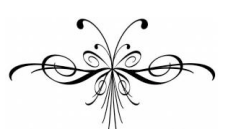

JOLANTA WAWRZYCKA

$\mathrm{I}$

$\mathrm{n}$ its many guises, sandwich is present in most cultures. The word "sandwich" appeared first in the journal of Edward Gibbons. ${ }^{1}$ Sandwich is named after John Montague (1718-1792), the Fourth Earl of Sandwich, who, as the lore has it, during a prolonged gambling binge that precluded dinner, "ordered his valet to bring him meat tucked between two pieces of bread. Because Montague also happened to be the Fourth Earl of Sandwich, others began to order 'the same as Sandwich!' The original sandwich was, in fact, a piece of salt beef between two slices of toasted bread". ${ }^{2}$ Montague's biographer, N. A. M. Rodger, asserts that the anecdote "refers to 1765, when Sandwich was a Cabinet minister and [was] very busy. There is no doubt, however, that he was the real author of the sandwich, in its original form using salt beef, of which he was very fond". Rodgers proposes, however, that Montague's invention most likely stems from the need to eat at his desk, especially since he worked long hours "in an age when dinner was the only substantial meal of the day, and the fashionable hour to dine was four o'clock". ${ }^{3}$ Whether by putting meat between slices of bread Montague tried to avoid soiling his cards or to get adequate sustenance during long hours in the office, Bloom would have liked the clean eater in him.

${ }^{1}$ OED: Gibbon's entry for November 24, 1762, records seeing a group of English upper crust gentlemen at the gaming club, The Cocoa Tree, dining noisily "a bit of cold meat, or a Sandwich."

${ }^{2}$ For more details see an informative "History of Sandwiches Website" by Linda Stradley at http://whatscookingamerica.net/History/SandwichHistory.htm (accessed on 6/18/09).

${ }^{3}$ Ibid. 


\section{"the language question" ( $U$ 8.466)}

Now, what of the word "sandwich" in other languages? With minor language-specific orthographical permutations, it has migrated and settled with ease outside English. It makes an early appearance in the 1930 Czech translation of Ulysses by Ladislav Vymětal. When Bloom is thinking about a sandwich, Vymětal uses "Obložený chlebíček?" (Cz/Vymětal 233; literally, "overlain bread", an equivalent of "sandwich"). However, when Bloom eventually asks for a sandwich, Vymětal opts for "sýrový sandwich" (cheese sandwich; 234). The 1977 Czech translation by Aloys Skoumal foregoes the foreignisation in favour of native Czech expressions: when Bloom thinks of having some "Chleba se šunkou" (bread with ham; Cz/Skoumal 161), he orders "sýrový chlebíček" (bread with cheese). Similar strategy is present in the Polish Ulisses of 1968, where Słomczyński has Bloom think "Kanapkę?" (Sandwich?) and ask "Czy są kanapki z serem?" (Do you have cheese sandwiches?), opting not to introduce the English borrowing. ${ }^{4}$ These choices allow translators to keep their respective Blooms on the level of ordinary men having an everyday mid-day snack (though their choice of burgundy as a beverage introduces a colourful touch).

The Russian Uliss features a phonetic transliteration of "sandwich" both when Bloom is thinking about his lunch selection, "Сандвич?" and when he orders "сандвич с сыром" (cheese sandwich; Ru/Hinkis-Horužij 131). Other choices might have included more common "sandwich" words used in Russian: a Germanic "бутерброд" (Butterbrot) or a French/Italian borrowing "тартинка" (tartin/tartina). Of course, "Madame Tartine" figures cleverly in the first French translation of 1929 (F/Morel 168), a solution not taken up by any other translators. By the time the Russian translation was published in 1998, the English borrowing had become a relative commonplace in European languages.

\footnotetext{
${ }^{4}$ Prof. Elzbieta Mańczak, an authority on English language borrowings in Polish, confirms (through Katarzyna Bazarnik, in private corespondence) that the word sandwicz is present in the so-called "Warsaw" Dictionary of the Polish language of 1902, though its use in Polish has been rather sporadic until more recent decades. In Polish, the Anglophone sandwicz corresponds to its original meaning of slices of bread overlaid with cold cuts or cheese, as does the Polish "kanapka." The latter, also denotes canapé, or Italian tartina, an open-faced and smaller morsel of buttered bread topped with cheese, ham, etc.
} 


\section{"the land of Ham" $(U$ 15.1901)}

Bloom's punning and allusive "Ham and his descendants mustered and bred there" cannot travel into Polish because the Polish word for ham, szynka, offers no Biblical echoes (as is the case with "ham" in other languages). This kind of challenge tests translators' skills and inventiveness. Słomczyński offers "Szynka i jej rodzinka z musztardą", that is, "Ham and its family with mustard." The internal feminine rhyme, szynka/rodzinka (ham and its family), with its sprightly trochee/amphibrach hop, suggest a nearjoke whose register, however, conjures up none of the biblical overtones. Those overtones are missing from the first Czech translation as well: Vymětal renders the sentence as "Šunka a její odvozeniny vyložené a vystrojené zde jako přehlídce (Ham and its derivatives spread out and arranged there like for a show, or, indeed, a "muster"). One notes a faint internal rhythm in Vymětal's "odvozeniny vyložené a vystrojené" and a hint of humour in the hyperbolic treatment of the spread. Skoumal, unlike Vymĕtal who keeps the šunka and lets go of Ham, opts to underscore the biblical allusion: "Ham a jeho pokolení rozdělené a rozplozené" (Ham and his descendants separated/divided and propagated). In the first case, the Czech readers get the image of ham products on show and, in the second, of dispersed descendants of Ham.

The Russian translators take a creative route to salvage both ham and Ham. To do so, they turn the Russian word for ham, ветчина, into a name, Ветчинкер. The solution, "Ветчинкер и суновья с горчицей и с хлебом" (Ham[ker] and sons with mustard and bread) may not resonate with obvious biblical echoes, but it helps that the Russian word for mustard, горчица, also connotes горчить (to taste bitter; one thinks of bitter herbs at Passover) and that Вет- in Ветчинкер stars like Ветхозаветный (i.e. Old Testament).

\section{"in a row" $(U$ 8.747)}

Like Ham, the "Sandwichmen" that appear earlier in Lestrygonians in their whitesmocked procession $(U$ 8.123) cannot fare all that well in translation either: they become just men walking in procession: in Polish, "rząd ludzi" (a row of people; Słomczyński 118); in Czech, a "průvod" (parade; Vymětal 209; Skoumal 145); in Russian, "цепочка людей” (line of people; Hinkis-Horužij 118). In French they are "Une file d'hommes" (Morel 173) and "Une procession d'hommes" (Aubert 225), as they are in Spanish, "Una processión de hombres" (Subirat 240), Italian, "Un corteo d'uomini" (I/De 
Angelis 159), "una processione di uomini" (I/Flecchia 120), and Portuguese, "Uma procissão de homens" (Houaiss 118).

The fact that the men are ad men is obvious in all translations, though the word "sandwichmen" works only in English, as does its echo, Sandwichers, the name applied to the natives of the Sandwich Islands on the Pacific Ocean (named so by Cook after the Fourth Earl of Sandwich in 1778; according to $O E D$ ). Whether the "cannibals" of the limerick imply sandwichmen/Sandwichers is impossible to determine. However, one does note the proximity of Bloom-the-ad-man's encounter with sandwichmen, his sandwich lunch, his thoughts of cannibals, and his "cannibalistic digestion" of the limerick.

Bloom's thoughts of "Dignam's potted meat" and "Cannibals would with lemon and rice" lead to reflections on kosher diet, the importance of digestion to the world's peace and war, and the mighty mitiness of cheese. The motif of cannibalism is foreshadowed when Bloom briefly peeks into Burton's and is continued at Davy Byrne's in the context of the dead and buried Dignam. But it also evokes the motif of sexual consumption that Bloom makes every effort not to think about: he is not, after all, the chief who consumes Molly's parts of honour. The limerick metonymically marks Bloom's anxiety about Molly's assignation with Boylan and erases the tool of that affair - Boylan's "something the somethings". The translators have to make decisions about what/who is being consumed and by what/whom.

Bloom's thought, "Expect the chief consumes the parts of honour" sets another translatorial trap, especially since that thought is followed by "Ought to be tough from exercise". The Polish translation renders Bloom's Expect as Likely: "Likely the chief eats the noblest bit" (Pewnie wódz zjada najszlachetniejszą czastkę; Słomczyński 131). The referent of Bloom's "Ought to be tough from exercise" is indeterminate: it could be the chief who is getting tough from the exercise of eating missionary's parts of honour; it could also be that the parts of honour are tough from exercise. The ambiguity of the original suffers in Polish, courtesy of an interpretive path: "Powinien być łykowaty od umartwiania" (He should be stringy-tough from mortification/flagellation). Although in Polish the suggestion is that mortification has made the missionary's flesh tough to chew, the grammar points to the chief who is stringy from mortification. But we get back on track in the next sentence in Polish where the chief's wives stand in a row (though are not engaged in a row) to observe the effect of their husband's consumption of the missionary's whole "hm," a creative, if gnomic, rendition of Bloom's elliptical "something the somethings". 
In the Russian translation, the grammar of Bloom's thinking is normalised: Expect becomes I think and the chief consumes is expressed in the "middle" voice, common to Slavic languages and back-translated here through the passive voice - "I think [that for] the chief selected are the honorary parts" (“Я думаю вождю выделяются почетные части", Ru/ HinkisHoružij 131). The sentence that follows back-translates as: "Toughened probably from strenuous exercise(s) (“Жестковаты наверно от усиленных упражнений'). Like the Polish translation, the Russian one implies that it is the chief who is toughened by exercise. Unambiguously, "All wives gathered around to see what will happen" ("Все жены собрались смотрят что будет"). Once again "row/row" does not travel out of English.

The 1930 Czech translation also normalises Expect: "The chief, [I] suspect, gets/receives the honorary parts" ("Pohlavár, tuším, dostává čestné části", Cz/Vymetal, 233). These parts, continues the Czech Bloom, "likely will be a little stiff from loyal service" ("Asi budou trochu tuhé od vĕrných služeb"). And the wives? Well, "His wives in a line devour/swallow the effects" ("Jeho ženy v šiku pozorují účinky"). The register of cannibalism appears to have shifted from the chief (the-recipient of missionary's parts) to the wives who "devour" the effect, though it is unclear what "effect" that might be. The 1977 Czech version glides over the ambiguity of the original as follows: "The chief likely manages/handles honorary bits" ("Náčelnik asi spořádá čestné kousky", Cz/Skoumal 161), where the third person singular "sporada" ("manages") has also suggestive overtones of "handles." Those honorary bits are "From swelling [from strain] likely quite stiff" ("Od namáháni asi dost tuhé"). The sentence with the wives, however, is missing.

\section{"a choice concoction" $(U$ 16.355)}

There is a sequence of phrases in Bloom's thinking ("who ate something the somethings of the reverend Mr Trigger/With it an abode of bliss") that culminates in "Lord knows what a concoction" (emphasis added). The subtle complexity of this sequence can hardly be salvaged in translation. Grammatically, the "something" from the limerick becomes the "it" "with it") from the Plumtree's potted meat ad, and then - a "concoction" (con-, coc-; "with "it"). In the passage where so many references are ambiguous, this progression, "something-it-concoction" appears to be quite clear. In Polish the word "concoction" is rendered as "mixture": "God knows what a mixture" ("Bóg wie, co za mieszanina"). Mieszanina is a feminine noun, devoid of reverberations built into "concoction" and the Polish Anglicism, 
"koktail", could be of service here. However, in Polish, "kok" has none of the semantic range of its English homonym (it refers to a beehive hairdo), which is why Molly's liking of the name Paul de Kock does not translate into Polish either. As we already saw, the Polish "hm" for Bloom's "something" is lexically noncommittal and the "it" of "with it an abode of bliss" reads as "Z nia szczęścia przybytkiem," where "z nią" (with her) refers to the feminine form of the pronoun "it" (for the "konserwa", a feminine for "potted meat"). Thus the progression "something-it-concoction" becomes in Polish "hm-her-mixture."

In Czech, Vymětal's solution for "Lord knows what a concoction" back-translates as "God knows what a hodge-podge this is" ("Bůh vi, jaká míchanice to je") and, as a bonus, the Czech "concoction," (feminine) "míchanice", carries also the echoes of "promiscuity". The "something" from the limerick ("cosi") parallels the original, though "with it (an abode of bliss)" changes in to (masculine) plural, "with them" ("S nimi"), to match the plural of "Masové konservy", that is, potted meat(s). The "something-itconcoction" becomes Polish "hm-her-mixture" becomes Czech "somethingthem-hodge-podge."

The Russian translation turns the noun "concoction" into a verbal phrase: "So they mixed it all up" ("Ну и намешали всево"). The limerick states that the Negro chief ("негритянский царек") "ate the Father on a summer day" ("Кушал патера в летний денек"). The ad phrase, "with it" appears as "с ними", or "with them" to match the plural of "паштетов Сливи", potted meat(s) seen also in Czech. But the limerick's elliptic "something" is absent from the translation. That absence affects the something-itconcoction progression of Bloom's thinking in Russian, especially since "concoction" is rendered as a verbal phrase.

Unfair as it is to apply such pedantic reading to languages that cannot always accommodate English lexis and semantics, the exercise is nevertheless enlightening for the insights that it provides into the original as well as into translators' labours.

\section{"corpse of milk" $(U$ 6.982)}

Bloom's choice of hygienic mid-day nourishment presents a sharp contrast to the unsavoury food choices made by his fellow Dubliners at Burke's. Cheese may be a "corpse of milk", but it "digests all but itself". The cleansing and therefore pacifying agency of cheese promises to purge the impurities of the kidney breakfast (and of his own kidneys when he registers 
"a quiet message from his bladder"; $U$ 8.933). Dietary vigilance promotes healthy digestion and peace, rather than Cyclopean bellicose posturing or off-the-chart hallucinations in Circe. Cheese in Joyce's text was at first "mity", then, for decades, "mighty", until it stood corrected in Gabler to become "mity" once again. That Joyce might have been punning on a "Mighty Cheese" ad of his time is one issue; what most of the translators had to work with is another. In Polish, "Mighty cheese" is rendered as "mocarny ser", a lucky semantic solution that connotes "mocarz" (powerful ruler) and "mocny" (strong); "mocarny" implies that the cheese, in its mightiness, does the job of mites too. In Czech, the cheese is "Účinný" (Skoumal), that is, beneficent, forceful, efficient, efficacious, energetic, operative and potent - all at once. Vymětal's cheese is "Veleúčinný" where the prefix vele-, (super-, highly, greatly) magnifies the above qualities. Alas, the Russian solution, “Был сух стал сыр" amounts to incomprehensibility. ${ }^{5}$

\section{"the chant arrested at the conclusion" $(U$ 17.765)}

This exercise brings into relief some of the dilemmas faced by the Polish, Russian and Czech translators of Ulysses and it takes stock of a selection of compensatory moves and solutions available in their respective languages. Those languages share some features in common - they are fusional, or inflecting, languages where gender, noun case, verb aspect, tense/mood and number are carried by morphemes that can form complex lexical units. On the one hand, these features account for the fantastic "flexilibility" of Slavic languages; Słomczyński said that: "[the] Polish language is very rich and has great elasticity". ${ }^{6}$ But Joyce's translatorial writing style inscribes similar malleability into English, which calls for extraordinary skills on the part of Joyce translators. As I argued elsewhere, the term "translation" could be replaced by such terms as re-languaging or trans-semantification to direct our attention to the polytropic turns that Joyce's works take as they travel out

\footnotetext{
${ }^{5}$ Unsure about my conclusion, I consulted my colleague, Russian native, Professor Grigory Ioffe, who stated in his e-mail: "I don't understand that sentence either. It's twisted. There's no such idiom. It doesn't seem to make sense unless one is rendering something that was equally twisted in the English original." More prodding on my part yielded the following: "makes me think that either the Russian translators took incredible, almost irrational liberty in twisting the original or (more probable) this is just some kind of a misprint. This translation is way off the mark."

${ }^{6}$ Maciej Słomczyński, “A Point of View” in James Joyce Quarterly 4 (Spring 1967): 236.
} 
of English and into other set of lexical and semantic parameters. ${ }^{7}$ The terms re-languaging / trans-semantification open up the range of the term "translation" to suggest that "translated" texts undergo more that just an interlingual transfer from one linguistic complex to another. That is to say, the terms, underscore the transformative force of translation, one that engenders semantic and lexical surplus in the target language. They also imply that translators labour greatly to accommodate in the target language such multivalent aspects of the source text as its literariness, its aesthetically relevant strata, Ingardenian polyphonic harmony, ${ }^{8}$ and Poundian logopoeia, ${ }^{9}$ to name just a few. Finally, re-languaging/trans-semantification speaks to the complexity of the solitary process of the re-fostering of a literary work in another sociolinguistic and socio-cultural milieu and it acknowledges translators' authorial role in preserving a work's relevance, its impact, its original core.

We have seen Bloom's sandwich transliterated (сандвич), foreignised, (sýrový sandwich) and re-languaged (sýrový chlebíček, kanapki z serem). We have also seen some creative salvaging, creative forgoing, and numerous logopoeic shifts. The thoughts of the Polish Bloom may be Joyceanly "bloomian" in some places, Polishly "everyman" in others, and funny in places that don't always coincide with the "funny" of the Irish Bloom. The Russian Bloom may occasionally resort to the middle voice and the Czech one may use plurals where other Blooms do not. But the translators, in their authorial role of re-fostering Bloom for their respective readers, have cocreated polytropic Blooms that stand to share a sandwich with their Irish counterpart.

\section{Jolanta Wawrzycka jolanta@radford.edu Radford University}

\footnotetext{
${ }^{7}$ The terms re-languaging and trans-semantification are defined in my "Tell us in plain words': Textual Implications of Re-Languaging Joyce", in Joyce and/in Translation, ed. Rosa Maria Bollettieri Bosinelli and Ira Torresi (Rome: Bulzoni, 2007): 39-50; see especially pp. 43-44.

${ }^{8}$ Ibid, p. 44.

${ }^{9}$ Pound states that logopoeia "employs words not only for their direct meaning, but it takes count in a special way of habits of usage, of the context we expect to find with the word, its unusual concomitants, of its known acceptances, and of ironic play. It holds the aesthetic content which is peculiarly the domain of verbal manifestation, and cannot possibly be contained in plastic or in music. It is the latest come, and perhaps most tricky and undependable mode". Ezra Pound, Polite Essays (London: Faber and Faber, 1937), p. 170
}

Scientia Traductionis, n.8, 2010 